\title{
Distracción mandibular y articulación temporomandibular
}

\author{
Mandibular distraction and the temporomandibular joint
}

\author{
F. Monje Gil
}

Resumen: Los pacientes con deformidades craneofaciales requieren generalmente multiples $y$, a veces, complejos procedimientos quirurgicos para reconstruir tejidos blandos y duros alterados. Un avance importante en cirugía reconstructiva es el alargamiento de la mandibula por distracción que tiene la ventaja de una cirugía menos agresiva que determinados tipos de osteotomías. Con esta técnica una osteotomía bicortical se hace en distintas zonas de la mandibula colocandose el distractor hasta alcanzar los efectos deseados. Aunque las fuerzas aplicadas se han mostrado eficaces para alargar la mandíbula, sus efectos en segmentos proximales y distales, incluyendo la articulación temporomandibular no han sido analizados sistemáticamente. En este artículo se repasa trabajos experimentales y clínicos en los que se detalla la relación entre distracción mandibular y articulación temporomandibular.

Palabras clave: Articulación temporomandibular; Distracción osteogénica; Reconstrucción mandibular.

La aplicación del concepto de distracción para el tratamiento de las deformidades craneofaciales comienza en el año $1972^{1}$ cuando se consigue realizar un alargamiento de la mandíbula de perro. Posteriormente otros trabajos experimentales $2,3,4$ han contribuido al conocimiento de distintos aspectos biológicos de este procedimiento. Su aplicación a la clínica humana comienza con los trabajos de McCarthy5,6 de tal manera que, a partir de él, consigue utilizarse este método de forma sistematizada en determinadas deformidades craneofaciales.

\section{Jefe de Servicio de Cirugía Oral Maxilofacial, Hospital Universitario Infanta Cristina}

\section{Correspondencia:}

Florencio Monje Gil

Servicio de Cirugía Oral y Maxilofacial. Hospital Univ. Infanta Elena

Crtra. de Portugal s/n - 06001 Badajoz

E-mail: fmonje@oralmaxilofacial.com

\begin{abstract}
Patients with severe craniofacial abnormalities often require multiple and complex surgical procedures to reconstruct maldeveloped hard and soft tissues of the maxillofacial complex. An important advance in reconstructive surgery is mandibular lengthening by gradual distraction, which takes advantage to be less agressive surgery than some osteotomies. With this technique, a bicortical osteotomy is made at the angle of the deficient mandible, and an expansion appliance is placed across the osteotomy line. Although the applied forces have been shown to lengthen the mandible effectively in the region of the application, their effects on the proximal and distal mandibular segments, including the temporomandibular joint region, have not been analyzed systematically. In this article, we study several experimental and clinical papers where it describes the relationship between mandibular distraction and temporomandibular joint.
\end{abstract}

Key words: Temporomandibular joint; Mandibular distraction; Mandibular reconstruction.

The concept of distraction applied in the treatment of craniofacial abnormalities began in the year $1972^{1}$ with the lengthening of the jaw of a dog. Later other experimental papers ${ }^{2,3,4}$ have contributed to the understanding of the different biological aspects of this procedure. Clinical application in humans began with the work of McCarthy, ${ }^{5,6}$ to the extent that, due to him, this method began to be used systematically for certain craniofacial abnormalities.

The Temporomandibular Joint (TMJ) is composed of the mandibular condyle, joint disc, temporal fossa, capsule and ligaments. The mandibular condyle has a mechanical function but it also has a growth function, which is to a certain respect adaptive. It is of interest to bear in mind that for this, the mandibular condyle has joint cartilage which serves in addition as growth cartilage. This growth cartilage has various layers: articular, proliferative, fibrocartilaginous and calcified. This organization is visible until adolescence. After this 
La Articulación Temporomandibular (ATM) está compuesta por el cóndilo mandibular, disco articular, fosa temporal, cápsula y ligamentos. El cóndilo mandibular tiene una función mecánica pero asimismo presenta una función de crecimiento, en cierto modo, adaptativo. Para ello es interesante tener en cuenta que el cóndilo mandibular posee un cartílago articular que además sirve como un cartílago de crecimiento. Este cartílago de crecimiento presenta varias capas: articular, proliferativa, fibrocartilaginosa y calcificada. Esta organización es visualizable hasta la adolescencia. Posteriormente la división nítida del cartílago articular en estas zonas es muy difícil de apreciar. Asimismo además de los condrocitos y otros componentes celulares del cartílago debemos saber que en este cartílago existe la matriz y la sustancia intercelular. La matriz está constituida por las fibras de colágena que, a su vez, son sintetizadas en el condrocito. Aporta gran resistencia a la tracción y, sin embargo, poca resistencia a la compresión. La sustancia intercelular está constituida por proteoglicanos y agua. Aporta gran resistencia a las fuerzas compresivas. En resumen, estamos ante una articulación muy compleja por diversas razones: variedad de los tejidos que la componen, actividad mecánica y de crecimiento, presencia de un disco articular muy importante en todas las funciones de la ATM, relación con los movimientos mandibulares $y$, en determinados casos, con factores oclusales. Pero por otra parte, esta articulación está dotada de una serie de características biológicas favorecidas por la riqueza en tejidos conectivos: regeneración, adaptación y remodelamiento. Sin embargo, estas características son fáciles de definir científicamente pero separar estos tres conceptos en la clínica es muy complicado

La distracción mandibular se asienta sobre una serie de principios biológicos: realización de osteotomía, preservación de la vascularización, adecuado periodo de latencia, correcto ritmo de distracción y acertado periodo de consolidación. ${ }^{7}$ Sin embargo, todavía no son conocidos muchos principios mecánicos entre los que destaca la relación de las distintas fuerzas generadas por la distracción mandibular y la ATM. Por otra parte, en varios trabajos experimentales 8,9 se ha comprobado la aparición de cambios en articulaciones, como la rodilla, en relación a la distracción de los huesos cercanos a la misma (fibrilación cartilaginosa, pérdida de proteoglicanos y necrosis cartilaginosa). Sin embargo, pocos han sido los trabajos que han estudiado la relación entre distracción mandibular, en los distintos planos del espacio, y la ATM.

La primera cuestión a dilucidar es si, verdaderamente, la distracción mandibular, en los distintos planos del espacio, produce una variación en la posición del cóndilo mandibular. El trabajo fundamental que se refiere a este aspecto es el de Samchukov. ${ }^{10}$ Se utiliza un modelo informático para visualizar el efecto de la distracción en el plano sagital dependiendo de si el distractor se coloca paralelo a la superficie ósea o paralelo al eje del distracción. Si se coloca paralelo al eje de distracción no hay ningún tipo de repercusión espacial sobre la posición condilar. Sin embargo, si se coloca paralelo a la superficie ósea por cada $\mathrm{mm}$ que se distrae existe un desplazamiento lateral del cóndilo mandibular de 0,25 mm. Según el mismo modelo cuando se utiliza una distracción transversal tras una osteotomía media mandibular existe una rotación interna del cóndilo mandibular. the clear division of the joint cartilage in this region is very difficult to appreciate. As well as condrocytes and other cellular components of the cartilage, we need to know that the matrix exists in this cartilage and intercellular substance. The matrix is made up of collagen fibers which are in turn synthesized in the chondrocyte. It provides great resistance to traction but little resistance to compression. The intercellular substance is made up of proteoglycans and water. It provides great resistance to the forces of compression. This, in short, is a very complex joint for different reasons: variety of the tissues that compose it, mechanical activity and growth. It is a very important articular disc for all the functions of the TM], [affecting] the relationship with mandibular movements and in certain cases, with occlusal factors. But on the other hand, the richness of the connective tissue contributes to a series of biological characteristics of the disc: regeneration, adaptability and remodeling. However, these characteristics are easy to define scientifically but separating these three factors clinically is very complicated.

Mandibular distraction is based on a series of biological principles: performing an osteotomy, preserving vascularization, adequate latency period, correct rhythm of distraction and correct consolidation period. ${ }^{7}$ However, many of the mechanical principles are still not known today which includes the relationship of the different forces generated by mandibular distraction and the TMJ. On the other hand, in various experimental works,9 the appearance of changes in joints, such as in the knee, in relation with the distraction of the bones near by, has been verified (cartilaginous fibrillation, loss of proteoglycans and cartilaginous necrosis). However, few works have studied the relationship between mandibular distraction, in the different planes of the space, and the TMJ.

What first has to be clarified is whether mandibular distraction, in the different planes of the space, really produces a variation in the position of the mandibular condyle. The essential work covering this aspect is by Samchukov'10. A computer model is used in order to visualize the effect of distraction in the sagittal plane depending on if the distractor is placed parallel to the surface of the bone or parallel to the axis of distraction. If it is placed parallel to the axis of distraction there is no type of repercussion in the space on the position of the condyle. However, if it is placed parallel to the bone surface, for every $\mathrm{mm}$ of distraction there is a lateral displacement of the mandibular condyle of $0.25 \mathrm{~mm}$. According to the same model, when distraction is carried out in the transverse dimension following a medial osteotomy of the mandible, there is an internal rotation of the mandibular condyle.

\section{Mandibular distraction in the transverse dimension and the temporomandibular joint}

The first experimental investigation was published by Harper and cols. ${ }^{11}$ The Macaca Mulatta was used as a model. 


\section{Distracción mandibular transversal y articulación temporomandibual}

El primer trabajo experimental publicado fue el de Harper y cols. ${ }^{11}$ Se utiliza un modelo que es el Macaca Mulatta. Se realiza osteotomía en la línea media mandibular. Comienza la distracción de 7 a 14 días después de la osteotomía y se continúa con un índice de 0,5 mm dos veces al día durante 7 a 10 días. Se realizó un análisis histológico de las distintas zonas de los cóndilos mandibulares. Los cambios en las zonas anterolaterales y posteromediales de estos cóndilos eran muy leves y afectaban fundamentalmente a la disposición de las fibras de colágena. Sin embargo, la aparición de cambios histológicos más severos ocurría en las zonas anteromediales y posterolaterales donde se apreciaba reabsorción dentro de la zona cartilaginosa y la aparición de una severa desorganización en la orientación de los haces de fibras de colágeno. Sin embargo no se conseguía observar erosiones en la superficie condilar. Estos cambios eran atribuidos a la presión que se ejercía sobre estas zonas del cóndilo por determinadas zonas de la fosa temporal. Sin embargo, los autores concluían que estos cambios eran adaptativos y reactivos frente a un tipo de fuerzas compresivas las cuales eran mejor toleradas cuando la cantidad diaria de distracción se repartía en varias fases. El siguiente trabajo experimental que estudia la relación de la distracción transversal y la ATM es el de Stelnicki. ${ }^{12}$ En este estudio se utiliza como modelo experimental el perro. Se trata de un trabajo muy complejo puesto que durante la distracción se combinan distintos movimientos siendo el fundamental la distracción transversal. Se aplica un periodo de latencia de 5 días y un ritmo de distracción de $1 \mathrm{~mm}$ por día. El periodo de consolidación es de 8 semanas. El análisis morfológico-macroscópico de la fosa y el cóndilo mandibular es el parámetro estudiado. En los distintos grupos estudiados se aprecian erosiones condilares de mayor o menor amplitud. Por lo tanto, este estudio demuestra que la distracción transversal, en las condiciones detalladas del estudio, promueve cambios severos degenerativos y que no desaparece tras el final de un periodo de consolidación de 8 semanas. Evidentemente los autores reconocen que todos estos cambios son producidos por fuerzas compresivas aplicadas contra el cóndilo mandibular. Sin embargo, una deficiencia del estudio es la ausencia de un correcto estudio histopatológico que profundizara en la ultraestructura de estos cambios y donde se observaran , por ejemplo, la afectación de los tejidos blandos como el disco o la cápsula articular.

El único trabajo clínico que existe para relacionar la distracción transversal y la ATM es el de Kewitt y Van Sickels. ${ }^{13}$ Se analizan los resultados obtenidos sobre distracción transversal mandibular en 23 pacientes. Se aplicó un periodo de latencia de 5 días y un ritmo de distracción de 0,75 mm por día divido en tres periodos de expansión día. Además de estudiar otros factores como son función neurosensorial, estructuras periodontales y dentales se estudia, desde el punto de vista clínico, la aparición de síntomas en relación con la ATM . De los 15 pacientes que resultaron válidos para este estudio 7 tenían síntomas preoparatorios de ATM de los que 5 mejoraron de estos sintomas y dos no presentaban ningún tipo de cambios después de la cirugía. Sin embargo, estos pacientes eran some-
An osteotomy was carried out on the mandibular midline. Between the seventh and fourteenth day after the osteotomy, distraction was carried out at a rate of $0.5 \mathrm{~mm}$ twice a day for seven to ten days. Histological analysis was carried out in the different areas of the mandibular condyles. The changes in the anterolateral and posteromedial areas of these condyles were very minor and affected fundamentally the distribution of collagen fibers. However, the appearance of more severe histological changes occurred in the anteromedial and posterolateral areas where reabsorption within the cartilaginous area could be appreciated together with the appearance of severe disorganization in the orientation of the bundles of collagen fibers. Nevertheless, no erosions were discernable on the condyle surface. These changes were attributable to the pressure on theses areas of the condyles by certain areas of the temporal fossa. However, the authors concluded that these were adaptation and reactive changes due to compression forces which were tolerated better when the daily distraction rate was distributed in various phases. The following experimental investigation which studied the relationship between distraction in the transverse dimension and the TMJ was by Stelnicki. ${ }^{12}$ In this study the dog was used as an experimental model. This was a very complex work as during the distraction different movements were combined, the essential one being distraction in the transverse dimension. A latency period of five days was applied and a rhythm of distraction of $1 \mathrm{~mm}$ per day. The consolidation period was 8 weeks. The parameter studied was the morphologic-macroscopic analysis of the fossa and mandibular condyle. In the different groups studied condylar erosion to larger or smaller extent was appreciated. Therefore, this study demonstrated that distraction in the transverse dimension, under the conditions set out in the investigation, produces severe degenerative changes which do not disappear at the end of the 8 week consolidation period. Obviously the authors recognize that all these changes are produced by the forces of compression applied on the mandibular condyle. However, what is lacking in the study is the absence of a correct histopathological study which explores in depth the fine structure of these changes, and in which the effect on soft tissues such as the disc and the joint capsule is observed.

The only existing clinical paper that relates distraction in the transverse dimension and the TMJ is by Kewitt and Van Sickels. ${ }^{13}$ The results obtained regarding mandibular distraction in the transverse dimension were analyzed in 23 patients. A latency period of 5 days was applied together with a daily rate of distraction of $0.75 \mathrm{~mm}$ divided into three expansion periods a day. As well as studying other factors such as neurosensory function, periodontal and dental structures, the appearance of symptoms related with the TMJ was studied from a clinical point of view. Of the 15 patients that were suitable for this study, 7 had preoperative symptoms of the TMJ, 5 of which showed improvement in these symptoms, and two did not show any type of change after surgery. 
tidos después de la distracción transversal a otro tratamiento ortodóncico con cirugía mono o bimaxilar sin saber qué puede atribuírse a la distracción, al tratamiento ortodóncico o a la cirugía ortognática.

\section{Distracción mandibular en el plano sagital y articulación temporomandibular}

El antecedente a los estudios experimentales en este campo fue el publicado por Ellis. ${ }^{14}$ Se utilizó un modelo experimental que fue Macaca mulatta. Se practicó una osteotomía sagital bilateral. En un grupo se realizó fijación rígida y en otro grupo se realizó una fijación intermaxilar. En el grupo de la fijación rígida se constató un desplazamiento posterior del cóndilo lo cual provoca una compresión de la vertiente posterior condilar contra la pared posterior de la fosa glenoidea del hueso temporal. El estudio histológico revelaba una reabsorción de la superficie posterior del cóndilo y de la superficie anterior de la espina post-glenoidea. El autor admite que estos cambios, en la clínica humana, pueden conducir a cambios degenerativos y anquilosis aunque reconoce que pueden entrar a formar parte de una serie de cambios remodeladores. Por lo tanto, éste puede ser un antecedente a los trabajos experimentales que estudian la relación de distracción mandibular en el plano sagital con la ATM.

El primer trabajo concretamente es el de McCormick. ${ }^{15}$ Se utiliza como modelo experimental el perro. La activación comienza en el día 10 después de la cirugía y el ritmo distracción era de $1 \mathrm{~mm}$ por día. En un grupo se llega a los $20 \mathrm{~mm}$ y en otro a los $10 \mathrm{~mm}$. El análisis de los resultados se realizó mediante tomografía axial computerizada. El aplanamiento de la pared posterior fue mayor en los cóndilos del grupo distracción de $20 \mathrm{~mm}$. No aparecen fenómenos de necrosis ni degeneración. Los cambios son mínimos en la fosa temporal. Además se producen cambios en el cóndilo contralateral a la distracción y los autores consideran que todos estos cambios son reversibles y transitorios.

Un artículo muy interesante es el de Karaharju-Suvanto y cols. ${ }^{16}$ Se utilizó un modelo experimental que es la oveja en crecimiento. Aplica tras una osteotomía un periodo de latencia de 5 días. El ritmo distracción es de 0,5 a $1 \mathrm{~mm}$ por día. Se utilizó un método histológico y se estudió la repercusión de esta distracción en distintos grupos de animales: a las 4,5, a las 20 y a las 52 semanas. En el primer grupo se apreciaba un adelgazamiento del cartílago y un aumento de la actividad osteoblástica. Se apreciaban cambios en el cóndilo contralateral pero más leves. En el segundo grupo los cambios del cóndilo homolateral eran muy leves y en el tercer grupo el cóndilo homolateral era casi similar al control. Los autores extraen una serie de conclusiones. La primera es que al realizarse en animales en crecimiento se entendía como cambios remodeladores y reversibles sin aparecer en ningún momento cambios degenerativos. La segunda conclusión es que la afectación de la articulación contralateral es mínima.

El siguiente estudio es el Zou y cols. ${ }^{17}$ Utiliza un modelo experimental que es la cabra y lo que trata de averiguar es la repercusión que tiene en la ATM distintos índices de distracción. Tras un
However, these patients were later given, following distraction in the transverse dimension, other orthodontic treatment with single or bimaxillary surgery, and it was not possible to know what was attributable to the distraction, the orthodontic treatment or orthognathic surgery.

\section{Mandibular distraction in the sagittal plane and the temporomandibular joint}

The previous experimental study in this field had been published by Ellis. ${ }^{14}$ The Macaca Mulatta was used as an experimental model. A bilateral sagittal osteotomy was carried out. In one group rigid fixation was used and in the other group intermaxillary fixation was used. In the group with rigid fixation a posterior displacement of the condyle was observed, which caused the posterior side of the condyle to be pushed against the posterior wall of the glenoid fossa of the temporal bone. Histological analysis revealed a reabsorption of the posterior surface of the condyle and the anterior surface of the post-glenoid spine. The author admits that these changes, in human clinical, can lead to degenerative changes and ankylosis, although he acknowledges that they may become part of a series of remodeling changes. Therefore, this study could be the antecedent of the experimental works which study the relationship between mandibular distraction in the sagittal plane and the TMJ.

The first work was in fact by McCormick. ${ }^{15}$ The dog was used as an experimental model. Activation was begun 10 days after surgery, and the rhythm of distraction was $1 \mathrm{~mm}$ per day. In one group $20 \mathrm{~mm}$ was reached and in another $10 \mathrm{~mm}$. The analysis of results was done using a computed axial tomography. The flattening of the posterior wall was greater in the condyles of the $20 \mathrm{~mm}$ distraction group. There was no evidence of necrosis or degeneration. There were minimal changes in the temporal fossa. In addition to this there were changes in the condyle on the contralateral side of the distraction. The authors considered that these were all reversible and transitory changes.

The article by Karaharju-Suvanto and cols ${ }^{16}$ is very interesting. Growing sheep were used as experimental models. A latency period of 5 days was observed after the osteotomy. The distraction rhythm was from 0.5 to $1 \mathrm{~mm}$ per day. A histological method was used and the repercussions of this [type of] distraction was studied in different groups of animals: at 4.5, 20 and 52 weeks. In the first group thinner cartilage could be appreciated together with an increase in osteoblastic activity. Changes were observed in the contralateral condyle but they were much smaller. In the second group the changes in the condyle on the same side were very small, and in the third group the changes in the condyle on the same side were nearly the same as those in the control group. The authors came to a series of conclusions. The first was that, as growing animals were used, these were remodeling and reversible changes and degeneration changes 
periodo de latencia de 7 días se aplicaba en un grupo un índice distracción de $1 \mathrm{~mm}$ por día (0,5 mm cada 12 horas). En otro grupo se aplicaba una distracción de $2 \mathrm{~mm}$ por día ( $1 \mathrm{~mm}$ cada 12 horas). El análisis histológico reveló que en el primer grupo los cambios podían ser considerados remodeladores y adaptativos y se centraban en la porción posterosuperior del cóndilo mandibular. Sin embargo, en el grupo de mayor índice de distracción diaria se apreciaba cambios claramente degenerativos. Para estos autores los cambios posiblemente no estén en relación con la cantidad de la distracción sino con el ritmo diario de la misma. Por tanto, la «rapidez» en la distracción tiene una serie de efectos negativos no solamente contra el callo de osificación sino también contra los cambios adaptativos de la ATM.

El estudio de Thurmuller y cols. ${ }^{18}$ utiliza un modelo experimental porcino. No había periodo de latencia y aplicaba una distracción, dependiendo del grupo, de 1, 2 o $4 \mathrm{~mm}$ por día hasta llegar a los $12 \mathrm{~mm}$. Realizaba un estudio radiográfico y un estudio morfológico muy interesante (análisis de la forma condilar y del tamaño, de la superficie condilar y de las características del disco articular). Estudiaba, por otra parte, los resultados a los 24, 60 o 90 días. Centrándonos en los resultados finales se apreciaba que en los grupos donde el índice diario era de 2 o $4 \mathrm{~mm}$, cuando se comparaba con el control, el cóndilo era de más pequeño tamaño y aumentaba la convexidad aunque no aparecían erosiones. Igualmente, cuando la distracción era de 2 o $4 \mathrm{~mm}$ por día el disco articular se adelgazaba en su porción más medial apreciándose cambios macroscópicos en la totalidad del disco articular homolateral a la distracción. Aunque estos cambios son muy evidentes en los grupos donde hay mayor índice diario de distracción los autores no saben atribuir si éstos son debidos a la remodelación o se trata de fenómenos claramente degenerativos.

En el estudio de Muhonen y cols. ${ }^{19,20}$ se utiliza como modelo experimental el conejo. Trata mediante una tomografía de emisión de positrones (PET) de averiguar cómo la radioterapia y la terapia inducidas por la cámara hiperbárica influyen en la ATM de animales que son sometidos a distracción mandibular. En el grupo control se aprecia como la distracción mandibular provoca un incremento en la captación en la ATM, utilizando el PET, cuando se emplea la distracción mandibular homolateral. Se considera que esto significa cambios adaptativos o remodeladores propios de la ATM. La radioterapia induce una disminución en la captación del trazador. Sin embargo, cuando estos animales son sometidos a la cámara hiperbárica vuelve a incrementarse la misma.

El primer estudio clínico es el de McCormick ${ }^{21}$ donde analiza mediante TAC los resultados en 10 pacientes que son sometidos a una distracción de $0,5 \mathrm{~mm}$ cada 12 horas durante un período de estabilización de 8 semanas. Los pacientes analizados sufrían una distracción unilateral y los resultados se resumían en que se apreciaba un aumento de volumen del cóndilo distraído, que éste se posiciona más recto y la fosa temporal no era modificada por ningún cambio.

Este mismo grupo 22 , en el año 1997, investigaba las consecuencias terapéuticas que sobre la ATM provocaba la distracción sagital mandíbular. Se basa en el concepto denominado «transporte óseo». En virtud de este concepto, determinado tipo de anomalías were never observed. The second conclusion was that the contralateral joint was minimally affected.

The following study was by Zou and cols. ${ }^{17}$ They used the goat as an experimental model and they aimed to investigate the repercussion on the TMJ of different levels of distraction. After a latency period of 7 days, a distraction rate was applied in one group of $1 \mathrm{~mm}$ per day $(0.5 \mathrm{~mm}$ every 12 hours). In the other group distraction was $2 \mathrm{~mm}$ per day (1 $\mathrm{mm}$ every 12 hours). Histological analysis revealed that in the first group the changes could be considered remodeling and adaptive changes, and that these were centered on the posterosuperior portion of the mandibular condyle. However, in the group that underwent the largest amount of distraction per day, there were clear signs of degeneration. For these authors the changes were not necessarily due to the amount lengthened, but to the daily distraction rhythm. Therefore, the «speed» of the distraction has a series of negative effects, not only regarding callus ossification but also the adaptation changes of the TMJ.

The study by Thurmuller and cols ${ }^{18}$ used the minipig as an experimental model. There was no latency period and the distractor was activated, depending on the group, at a rate of 1, 2 or $4 \mathrm{~mm}$ per day until $12 \mathrm{~mm}$ was reached. A radiographic study was carried out together with a very interesting morphological study (analysis of condylar size and form, condylar surface area and characteristics of the joint disc). The results at 20,60 and 90 days were also studied. The final results showed that, when compared with the control group, the groups in which the daily rate was 2 to $4 \mathrm{~mm}$, the condyle was smaller with increased convexity, although erosion was not observed. When distraction was between 2 and $4 \mathrm{~mm}$ per day, the joint disc was thinner at its more medial portion, and macroscopical alterations could be appreciated in the whole of the joint disc on the same side of the distraction. Although these changes were very obvious in the groups which underwent the largest rate of distraction, the authors were not able to establish if this was due to remodelation or if it was due to a clearly degenerative phenomenon.

In the study by Muhonen and cols 19,20 the rabbit was used as an experimental model. The aim was to investigate using PET how radiotherapy and therapies using the hyperbaric [oxygenation] chamber affect the TMJ of animals who are subjected to mandibular distraction. The control group showed mandibular distraction led to increased detection in the TMJ using PET, when homolateral distraction of the mandible was used. This was taken to signify that these adaptation or remodeling changes were characteristic of the TMJ itself. Radiotherapy led to reduced detection of the tracer. However, when these animals were treated in the hyperbaric [oxygenation] chamber, there was an increase again.

The first clinical study was by McCormick ${ }^{21}$ who analyzed using a CT scan the results in 10 patients who had undergone a distraction of $0.5 \mathrm{~mm}$ every 12 hours during a stabilization period of 8 weeks. The patients analyzed had unilateral distraction and the results showed an increase in 
mandibulares de tipo congénito o traumático podían solucionarse mediante el transporte de un fragmento mandibular dirigido hacia la fosa temporal. Hay otros trabajos ${ }^{23-25}$ que apoyan este proceder terapeútico. La opinión de este grupo se contrapone a la de otros autores como Eppley ${ }^{26}$ que propugnan una reconstrucción primaria de la ATM en caso de déficit congénito, déficit postresección de la anquilosis o déficits traumático mediante un injerto condrocostal siguiendo la técnica clásica. Posteriormente, dependiendo de los resultados funcionales y estéticos puede someterse a una distracción la mandíbula que recibió previamente este injerto.

En consecuencia, al examinar la literatura publicada puede concluirse que:

- La distracción mandibular en los planos sagitales o transversales provoca cambios posicionales condilares.

- La distracción en el plano transversal produce cambios articulares importantes que pueden ser remodeladores, reactivos y/o claramente degenerativos.

- La edad es muy importante. Parece que cuando se trata de la aplicación de la distracción en individuos en crecimiento los cambios producidos son menos importantes y transitorios.

- Es más importante el ritmo de distracción diario que la cantidad total a distraer.

- Es necesario protocolizar desde el punto de vista clínico como puede utilizarse la distracción en la reconstrucción de la ATM.

- En la actualidad existen muy pocos trabajos científicos que relacionen, desde el punto de vista clínico, cuáles son las repercusiones que la distracción mandibular tiene sobre la ATM y cómo puede ser protocolizado el tratamiento de la patología que pudiera parecer en relación con ella.

\section{Bibliografía}

1. Snyder CC, Levine GA, Swanson HM. Mandibular lengthening by gradual distraction: preliminary report 1973;51:506-508.

2. Michieli S, Miotti B. Lengthening of mandibular body by gradual surgical-orthodontic distraction. J Oral Surg 1977;35:187-192.

3. Karp NS, Thorne CH, McCarthy JG. Bone lengthening in the craniofacial skeleton. Ann Plast Surg 1990;24:231-237.

4. Karp NS, M cCarthy JG, Schreiber JS. Membranous bone lengthening: A serial histological study. Ann Plast Surg 1992;29:2-7.

5. McCarthy JG. The role of distraction osteogenesis in the reconstruction of the mandible in unilateral craniofacial microsomia. Clin Plast Surg 1994;21:753-758.

6. McCarthy JG, Schreiber J, Karp N. Lengthening the human mandible by gradual distraction. Plast Reconstr Surg 1992;89:1-10.

7. McCarthy JG, Stelnicki EJ, Mehrara BJ. Distraction Osteogenesis of the Craniofacial Skeleton. Plast Reconstr Surg 2001;107:1812-1827.

8. Stanitski DF. The effect of limb lengthening on articular cartilage. An experimental study. Clin Orthop Relat Res 1991;301:68-72.

9. Nakamura E, Hiroshi M, Takagi K. Knee articular cartilage injury in leg lengthening: histological studies in rabbits. Acta Orthop Scand 1993;64:437-440.

10. Samchukov ML, Cope JB, Harper RP. Biomechanical considerations of mandibular lengthening and widening by gradual distraction using a compuer model. J Oral Maxillofac Surg 1998;56:51-59. the volume of the condyle on the distracted [side]. The latter was more erect and the temporal fossa had not been affected by the change.

This same group 22 in the year 1997, investigated the therapeutic consequences that sagittal mandibular distraction had on the TMJ. This was based on the "bone transport» concept. By virtue of this concept, certain types of mandibular anomalies, either congenital or traumatic could be solved by transporting a fragment of mandible towards the temporal fossa. There are other works ${ }^{23-25}$ supporting this therapeutic procedure. The opinion of this group is opposed by other authors such as Eppley 25 who support primary reconstruction of the TMJ in congenital defect cases, postresection defects arising from ankylosis or traumatic defects, by means of a costochondral graft following the classical technique. Depending on the functional and aesthetic results, the mandible with the graft can subsequently be lengthened.

As a consequence of examining the published literature, the following can be concluded:

- Mandibular distraction in the sagittal or transverse dimension leads to changes in the position of the condyles.

- Distraction in the transverse plane leads to considerable changes in the joints that can be remodeling, reactive and/or clearly degenerative changes.

- Age is very important. When distraction is carried out in growing individuals, it would appear that the changes that take place are transitory and less important.

- The daily rhythm of distraction is more important than the total amount of the distraction

- From a clinical point of view there should be a protocol regarding the use of distraction in TMJ reconstruction.

- There are very few scientific studies that establish from a clinical point of view, the repercussions of mandibular distraction on the TMJ and the protocol that should be established in this sense for treating this pathology. 
11. Harper RP, Bell WH, Hinton RJ. Reactive changes in the temporomandibular joint after midline distraction. Br J Oral Maxillofac Surg 1997;35:20-25.

12. Stelnicki EJ, Stucki-McCormick SU, Rowe N. Remodeling of the temporomandibular Joint following mandibular distraction osteogenesis in the transverse dimension. Plast Reconstr Surg 2001;107:647-658.

13. Kewitt GF, Van Sickels JE. Long term effect of mandibular midline distraction osteogenesis on the status of the TM], teeth, periodontal structures and neurosensory function. J Oral Maxillofac Surg 1999;57:1419-1425.

14. Ellis E, Hinton RJ. Histologic examination of the temporomandibular joint after mandibular advancement with and without rigid fixation: An experimental investigation in Adult Macaca mulatta. / Oral MaxiIlofac Surg 1991;49:1316-1327.

15. McCormick SU, McCarthy JG, Grayson BH. Effect of mandibular distraction on the temporomandibular joint. Part 1: canine study. / Craniofac Surg 1995;6:358-363.

16. Karaharhu-Suvanto T, Peltonen J, Ranta R. The effect of gradual distraction of the mandible on the sheep temporomandibular joint. Int J Oral Maxillofac Surg 1996;25:152-156.

17. Zou S, Hu J, Wang D. Changes in the temporomandibular joint after mandibular lengthening with different rates of distraction. Int J Adult Orthod Orthognath Surg 2001;16:221-225.

18. Thurmuller $P$, Troulis MJ, Rosenberg A. Changes in the condyle and disc in response to distraction osteogenesis of the minipig mandible. J oral maxillofac Surg 2002;60:1327-1333.

19. Muhonen A, Peltomaki T, Knuuti J. Osteoblastic activity of the rabbit temporomandibular joint during distraction osteogenesis assessed by fluoride positron emission tomography. Eur J Oral Sci 2002;110:144-148.

20. Muhonen A., Peltomaki T., Hinkla S. Effect of mandibular distraction osteogenesis on temporomandibular joint after previous irradiation and hyperbaric oxygenation. Int J Oral Maxillofac Surg 2002;31:397-404.

21. McCormick SU, McCarthy JG, Grayson BH. Effect of mandibular distraction on the temporomandibular joint. Part 2: Clinical study. J Craniofac Surg 1995;6:364-367.

22. Stucki-McCormick SU. Reconstuction of the mandibular condyle using transport distraction osteogenesis. / Craniofac Surg 1997;8:48-52.

23. Braun S, Bottrel A, Legan H. Condylar displacement related to mandibular symphyseal distraction. Am / Orthod Dentofacial Orthop 2002;121:162-165.

24. Cascone P, Agrillo A, Spuntarelli G. Combined Surgical therapy of temporomandibular joint ankylosis and secondary deformity using intraoral distraction. J Craniofac Surg 2002;13:401-410.

25. Cavaliere C, Buchman S. Mandibular distraction in the absence of an ascending ramus and condyle. J Craniofac Surg 2002;13:527-532.

26. Eppley BL. Distraction lengthening of the mandibular costochondral graft: A precautionary note. J Craniofac Surg 2000;11:350-353. 